\title{
Policy Transfer: A Classification of the Extant Literature into Waves, A Critique of the Existing Waves and A Proposal for a New Wave
}

\author{
Lucky Benson \\ Department of Political Science and Administration \\ Faculty of Social Science \\ Adamawa State University Mubi, Nigeria \\ E-mail: luckybensonkarfe@gmail.com
}

Received: Dec. 6, 2020 Accepted: Feb. 1, $2021 \quad$ Online published: Feb. 25, 2021

doi:10.5296/jpag.v11i1.18040～URL: https://doi.org/10.5296/jpag.v11i1.18040

\begin{abstract}
This paper presents a critical review of the extant literature on policy transfer. The aim is to classify transfer literature into waves, highlight the problems with the existing waves and propose a new wave that addresses the limitations in the extant literature. The purpose is to make theoretical contribution to the literature on policy transfer especially in the areas that the existing waves have ignored. The first part of the paper is organised around concepts associated with the extant literature on the first wave of policy transfer. The focus is on the work of Rose $(1991,1993)$ on lessons drawing as a driver to Dolowitz and Marsh (1996, 2000) famous literature on policy transfer. This is then followed by the second wave of policy transfer literature. The focal point of the second wave is a critique of the literature on the first wave of policy transfer. Following on for this second wave of policy transfer literature is a new wave that addresses the problems raised in the extant literature on the first and second waves of policy transfer. This is important because it provides the opportunity to cover the limitations of the first and second waves literature on policy transfer and make theoretical contributions.
\end{abstract}

Keywords: public policy, policy transfer, public sector reforms

\section{Introduction}

In the era of globalisation, policy making is no longer an exclusive right of the national governments in both the global north and the global south. Policy ideas, institutions, public 
sector reform, programs and e-government strategies are in many cases sourced outside national boundaries to solve domestic problems especially in LDCs across Africa. Many of such reforms are inspired by the ideas of new public management and e-government strategies in the continent. New Public Management (NPM) and e-government strategies originated mainly from the European countries and the USA in the global north. Evidence across Africa shows that domestic policy actors recognised the challenges of service delivery in the continent and identified the need for international solutions to solve domestic problems even with no clear evidence that the so called global solutions can address domestics peculiar challenges. However, in most cases, the transfer of such USA and Europe formulated solutions was mainly conditional rather than voluntary engagement by the African local policy actors. This is the case because donors used financial aid, loan and technical assistance as conditions for policy transfer and public sector reforms across the continent (Anonymous, 2018).

The transfers were based on the number of assumptions. These include: that LDCs across Africa given their economic conditions, would effectively implement such reforms for fear of losing the much needed financial aids, loans, and technical assistance that come as a condition for program and reform acceptance. This is in line with the argument that a “...political leader in a Third World country has little alternative but to accept the policies imposed by the World Bank or the IMF given that the consequences of refusal are deepening debt and economic and, probably, political crisis" (Dolowitz and Marsh, 1996:245). This made donors the major agents of policy transfer and public sector reforms from the global north to LDCs in Africa. However, as this study demonstrates that the use of conditions to enforce policy transfer from the global north to Africa may not necessarily lead to the expected outcomes of implementation. This is because domestic non-elite policy actors not international donors implement public sector reforms in Africa.

The second assumption is that local contextual factors are suitable for the implementation of the USA and Europe formulated policy across Africa. This made international policy actors to overlook the domestic contextual factors, and only coerce local political office holders to accept international reforms without engaging other critical domestic non-elite policy actors before the adoption of the transfer. This paper argues that the effective roll-out of reform strategies from the global north is not an automatic process even when conditions were attached to the policy transfer in Africa. This is the case because country's specific infrastructures, political commitment, and the citizens' acceptance of reforms matter for the effective roll-out of reform strategies across Africa (Anonymous, 2018; Benson, 2018; Tambulasi, 2011).

This paper classifies the extant literature on policy transfer in first, second, and third waves. It highlights their key arguments and limitations and proposes a new wave that addresses the lacuna in the extant literature on policy transfer.

\section{The First Wave Literature on Policy Transfer}

The aim of this section is to review the extant literature on the first wave of policy transfer. The section begins by referencing the work of Rose $(1991,1993)$ on lesson drawing because 
Dolowitz and Marsh (1996) well-known literature on policy transfer benefited for the most part from Rose's work.

The work of Rose (1991, 1993), Dolowitz, and Marsh (1996, 2000) are regarded in this study as the first wave literature on policy transfer. These literature represent the earliest work on the concepts of lesson-drawing and policy transfer as alternatives to domestic policy development across political systems. While the scope of the two literature vary, they are all concerned with a process in which public sector reform strategies in one political system in the past or present is used in development of reform ideas in another jurisdiction (Dolowitz \& Marsh, 1996; Rose, 1991). This means that when governments are faced with problems, their policy makers can learn lessons on how their counterparts in other political systems responded to such problems and solved them.

Lesson drawing has been described by Rose as: '... a short cut, utilising available experience elsewhere to devise a programme that is new to the agency adopting it and attractive because of evidence that is has been effective elsewhere' (Rose, 1991:7). It implies a voluntary engagement by policy actors in search of solutions to solve domestic problems. The reason for policy transfer from another political system can also be coercive or conditional depending on the drivers propelling policy actors to engage in such exercise. It is in this context that Dolowitz and Marsh (1996) preferred not to use the concept of lesson drawing and policy transfer interchangeably. This is the case because lesson drawing focuses only on voluntary transfer while the concept of policy transfer in the first wave literature includes: voluntary and coercive drivers for policy transfer (see Dolowitz \& Marsh, 1996; 2000).

In the first wave literature on policy transfer, the search for satisfaction across time and space by the relevant policy actors has been identified as one of the reasons for transfer to occur (Rose, 1991, 1993). In addition, the literature places: '...more emphasis upon how governments, international organisations and transnational companies can push other governments into policy transfers' (Dolowitz \& Marsh, 1996:344). As a result, the first wave literature prioritises the external drivers for policy transfer and ignored the critical domestic factors that can cause policy transfer to occur with or without international pressure for reform especially in LDCs (Anonymous, 2018).

Similarly, the first wave literature assumed that the use of coercive modalities of transfer by donors or direct policy imposition can push government in LDCs to effectively implement transferred policies when the issues relating to incomplete, uninformed and inappropriate transfers are addressed (see Dolowitz \& Marsh, 1996, 2000). But this study demonstrates that domestic factors and actors not international pressures shape the outcome of implementation of transferred policies across political systems especially in Africa. The critical concepts that emerged from the first wave literature on policy transfer that are related to the causes of policy transfer and the factors that shaped the outcome of transfer are analytically discussed below.

\section{Coercive Policy Transfer}

Coercive policy transfer is a direct imposition of policies or reform strategies on one political 
system by international donor organisations and countries. It is an external driver for policy transfer and public sector reform across political systems. This causes policy transfer when governments and international institutions force another government to adopt a policy or institution against their will and the will of their people (Dolowitz \& Marsh, 1996; 2000). Coercive transfer: '... entails a compulsion to conform and the use of power' (Stone, 2000:49) by powerful political systems and institutions to ensure compliance. It is in this context that Dolowitz and Marsh (1996:347) argued that the most direct method of coercive transfer is: '...when one government forces another to adopt a policy'.

Coercive approach to policy transfer was common during the colonial era across Asia and Africa. This is because the colonial powers used their military might to ensure compliance in their colonial territories. In this context, Stone (1999:55) argues that: '...the era of imperialism of last century resulted in significant coercive transfers of legal codes, parliamentary institutions, currencies and bureaucratic structures in the European colonies of Asia, Africa and Latin America'. Britain transferred its Westminster model of public service during the colonial regime and the parliamentary democracy at independence to her former colonies and many countries across Africa (Adebayo, 1981; Adegoroye, 2006). The problem is that coercive policy transfers are no longer common across political systems in the $21^{\text {st }}$ century. This is the case because many political systems are sovereign entities that cannot easily be coerced into adopting policies against their will. Thus, the emphasis in the first wave literature on the coercive modalities as a major external driver for policy transfer across LDCs is no longer tenable. It is highly contestable because all political systems in Africa are sovereign entities, so none is still under colonial regime across the continent.

Another limitation of the first wave literature on policy transfer is that it assumes the use of coercive force by donors to impose policy transfer across political systems would lead to an effective implementation of the transferred policies (see Benson, 2018; Dolowitz \& Marsh, 1996, 2000). This is the case because failure to implement donors' conditions and reform would lead to economic and political crises in LDCs. The first wave literature on policy transfer emphasis that external factors are not only pivotal in pushing Africa governments to accept international consensus but to also implement them (see Dolowitz \& Marsh, 1996; Rose, 1991). Consequently, the first wave literature on policy transfer placed more emphasis on donors' conditions as both the causes of transfer and the determinants of the outcome of implementation of transfer across LDCs. As a result, it ignores the relevance of local contextual factors and the role of non-elite domestic actors as causes of transfer and the determinants of the effective implementation of the transferred policies across political systems in Africa.

\section{Voluntary Policy Transfer/Lessons-Drawing}

The second driver for transfer identified in the first wave literature on policy transfer is: '...some form of dissatisfaction or problem with the status quo' (Dolowitz \& Marsh: 1996:346). Voluntary policy transfer occurs in the absence of both direct and indirect imposition of policy on one government by one or more political systems and institutions (see Dolowitz \& Marsh, 1996; Rose, 1991, 1993). This form of transfer happens when 
government policies stop delivery solutions to old problems or are consider not good enough to solve both old and new domestic challenges. It is in this context that Rose (1991:10) suggests that: '...when confronted with dissatisfaction, policymakers will search for something that will work, that is, be effective in dispelling dissatisfaction'. Dissatisfaction comes from the perception by government or the citizens of policy failure which would make policy actors to engage in a search for solutions.

Similarly, the first wave literature on policy transfer emphasis that the desire for international acceptance and the emergence of an international consensus would act as a voluntary driver for policy transfer to occur (see Dolowitz \& Marsh, 1996; Rose, 1991). This is the case because country would adopt transfer to avoid lagging behind other countries that have already implemented the internationally endorsed policy. As a result, national governments could respond to international pressures to implement internationally endorsed reform strategy without being forced to do so by the donor organisations and countries (Dolowitz \& Marsh, 1996; Rose, 1991). In addition, the potential mobility of multi-national business organisations from a political system can force government to transfer and implemented policies capable of attracting new businesses and the old ones to remain (Bennett, 1997). The argument for voluntary policy transfer as a driver and a determinant of the outcome of transfer is that: '...not only are there common problems but also a common response, regardless of partisan values or political cultures' (Rose, 1991:9).

The problem is that this argument ignores other local factors capable of compelling local policy actors to engage in a search for quick solutions to solve domestic problems. It also assumes that when policy actors engage in a voluntary search for satisfaction as a result of dissatisfaction with the status quo, it would automatically lead to an effective roll-out of the transferred policies. In addition, the literature prioritises dissatisfaction with the status quo as a determinant of the outcome of implementation of the transferred policies across political systems especially in Africa. Dissatisfaction is one of the explanatory variables for the causes of policy transfer but is not a determinant of the outcome of the effective implementation of transfer in LDCs. As this study demonstrates, critical domestic factors and actors are the determinants of the outcome of transfer not dissatisfaction with the status quo in Africa.

In addition, a key limitation of the first wave literature on policy transfer is that it focuses more on the voluntary policy transfer between developed countries (see Evans \& Davies, 1999; Evans, 2004). As a result, policy transfer activities across LDCs especially in Africa are reasonably under-researched.Consequently, many of the key assumptions and conclusions of the extant literature on policy transfer are based on the experiences of countries in the global north not on empirical findings in political systems in Africa. However, the experiences of countries in the global north on policy transfer may not necessarily be the same with countries in the global south. This partly explains why some of the assumptions about policy transfer in Africa in the extant literature are contestable.

\section{Actors Involved in Policy Transfer}

The literature on lesson drawing identifies epistemic communities and intergovernmental institutions as different categories of policy actors involved in transfer from one jurisdiction 
to another (Rose, 1991, 1993). Other agents of policy transfer identified in the first wave literature on policy transfer include: '...elected officials, political parties, bureaucrats/civil servants, pressure groups, policy entrepreneurs/experts, and supra-national institutions' (Dolowitz \& Marsh, 1996:345). The roles of these actors as agents of policy transfer across political systems have been examined in the first wave literature on policy transfer (see Rose, 1991, 1993; Dolowitz \& Marsh, 1996, 2000). These policy actors play important role in the spread of policies, programs, institutions among others across political systems especially from the global north to Africa. What has not been discussed perhaps is how domestic non-elite policy actors shaped the outcome of implementation of transferred policies and reform strategies across political systems in Africa.

The problem is that the first wave literature on policy transfer prioritises the role of elite actors in policy transfer. It places more emphasis on the role of international donor organisations and countries at the expense of the key role domestic actors play in policy transfer in Africa. Consequently, it neglected the critical role of non-elite actors in shaping the outcome of implementation of the transferred policies across political systems in LDCs. However, increasingly, domestic policy actors such as career public servants, political parties, academics, policy experts, students among others are engage in policy transfer from the international arena into their political systems especially in Africa. They are mostly engaged in transfer when they attend formal educational trainings overseas, conferences, and official case study visits outside their national boundaries.

This study argues that apart from being agents of policy transfer, domestic policy actors including non-elite actors also play a critical role of determining the outcome of implementation of the transferred policies across Africa. This is the case because they are officially required to implement government policies including the transferred reform strategies and programs in their jurisdictions. In addition, local policy actors not international donor countries and organisations, determine the actual allocation of human and material resources necessary for the effective roll-out of reform strategies in Africa. But the critical roles of domestic policy actors in resources allocation and policy implementation have been ignored by the first wave literature on policy transfer across LDCs.

Table 1. Summary of the First Wave Literature on Policy Transfer Framework

\begin{tabular}{|c|c|c|c|}
\hline $\mathbf{s} / \mathbf{n}$ & Key Issue & $\begin{array}{l}\text { Dolowitz and Marsh }(1996,2000) \\
\text { explanations }\end{array}$ & Major Critique \\
\hline 1 & $\begin{array}{l}\text { Causes of policy } \\
\text { transfer }\end{array}$ & $\begin{array}{l}\text { Coercive pressure. One or } \\
\text { more governments/donors can } \\
\text { force another government to } \\
\text { accept a new policy } \\
\text { The use of conditional } \\
\text { modalities of transfer by } \\
\text { donors can lead to policy } \\
\text { transfer } \\
\text { Voluntary transfer is cause by } \\
\text { dissatisfaction with the status }\end{array}$ & $\begin{array}{l}\text { - Ignores domestic } \\
\text { factors that can cause } \\
\text { policy transfer to } \\
\text { occur with or without } \\
\text { international pressure } \\
\text { for reform in LDCs } \\
\text { Both international } \\
\text { pressures and } \\
\text { domestic factors are } \\
\text { responsible for policy }\end{array}$ \\
\hline
\end{tabular}




\begin{tabular}{|c|c|c|c|}
\hline & & by policy actors & transfer in LDCs \\
\hline 2 & $\begin{array}{l}\text { Factors that determine } \\
\text { the effective } \\
\text { implementation of } \\
\text { transfer }\end{array}$ & $\begin{array}{l}\text { - International pressure } \\
\text { can push governments } \\
\text { to implement policy } \\
\text { transfer for fear of } \\
\text { lagging behind and } \\
\text { losing the benefits of } \\
\text { transfer } \\
\text { Uninformed, } \\
\text { incomplete and } \\
\text { inappropriate transfer } \\
\text { as reasons for } \\
\text { implementation } \\
\text { failure }\end{array}$ & $\begin{array}{l}\text { Domestic factors and } \\
\text { actors not only } \\
\text { international } \\
\text { conditions shaped the } \\
\text { outcome of } \\
\text { implementation of } \\
\text { transfer in LDCs } \\
\text { They focus more on } \\
\text { reasons for policy } \\
\text { transfer failures rather } \\
\text { than factors that } \\
\text { shaped the effective } \\
\text { implementation of } \\
\text { transfer especially in } \\
\text { LDCs }\end{array}$ \\
\hline 3 & $\begin{array}{l}\text { Actors involved in } \\
\text { policy transfer }\end{array}$ & $\begin{array}{l}\text { Domestic and international } \\
\text { policy actors } \\
\text { - } \quad \text { Emphasis on the elite actors }\end{array}$ & $\begin{array}{l}\text { Does not clearly explain the } \\
\text { role of local policy actors in } \\
\text { the implementation of the } \\
\text { transferred policies across } \\
\text { political systems especially in } \\
\text { LDCs } \\
\text { Neglected the role of non-elite } \\
\text { actors in policy transfer } \\
\text { especially in LDCs }\end{array}$ \\
\hline
\end{tabular}

Source: Literature review

\section{The Second Wave Literature on Policy Transfer: A Critique of the First Wave}

The preceding section presented a review of the extant literature on the first wave of policy transfer. The section started the discussion by referencing the work of Rose $(1991,1993)$ on lesson drawing as the driver to Dolowitz and Marsh (1996) renowned literature on policy transfer. This section presents the second wave literature on policy transfer.

The second wave literature are those that critiqued the work of Rose $(1991,1993)$ on lesson drawing and Dolowitz and Marsh $(1996,2000)$ on policy transfer. These include the works of Evans and Davies (1999), Evans (2004, 2009), James and Lodge (2003) and so on. These literature have acknowledged that Dolowitz and Marsh had led efforts in putting together concepts to develop a framework for the study of policy transfer. However, they noted that Dolowitz and Marsh (1996) framework on: '...policy transfer analysis does not have full explanation' (Evans \& Davies, 1999:364) of the domestic and international circumstances that are likely to bring about policy transfer to occur. Dolowitz and Marsh (1996) explanations on why policy transfer happens: '...places more emphasis on globalisation processes and ignored domestic factors' (Evans \& Davies, 1999:365) that can cause policy transfer especially in LDCs. As a result, the roles of domestic factors in causing policy transfer across political systems are largely neglected in the first wave literature.

Another limitation of the first wave literature on policy transfer is that it: '...focused 
exclusively on the study of policy transfer between developed countries' (Evans, 2009:244). As a result, the dynamics of policy transfer activities in the global south are largely under-researched. Consequently, many of the issues regarding policy transfer in the global south are based on assumptions not empirical evidence. In addition, rather than identifying the factors that shaped the outcome of policy transfer, the first wave literature describes policy implementation: '...failure as different forms of transfer' (James and Lodge, 2003:179). Thus, there is little emphasis on how domestic factors and actors shape the outcome of policy transfer across political systems especially in Africa.

\section{Key Arguments in the Second Wave Literature on Policy Transfer}

Sequel to the limitations highlighted in the first wave literature on policy transfer, the second wave literature advocated for: ' ... a multi-level action based approach to the study of policy transfer' (Evans, 2009:243). It argues for the need to consider domestic and international circumstances that are likely to bring about policy transfer to occur across political systems (see Evans, 2009; Evans \& Davies, 1999; James \& Lodge, 2003). This is the case because policy transfers analysis that recognises the importance of external factors and domestic structures and their ability to affect outcome would give full understanding of the dynamics of transfer across political systems. But the problem is that the second wave literature also focused on the study of policy transfer in the global north with little attention on transfer activities in the global south. It places more emphasis on the use of conditional modality of transfer by donors as the major causes of policy transfer across political systems especially in LDCs.

Conditional policy transfer refers to the use of incentives to influence transfer or punish those who refuse to transfer (Evans, 2004; 2006). Recipient governments are compelled by the powerful: '...donor countries, global financial institutions, supranational institutions, international organisations or transnational corporations to introduce policy change in order to secure grants, loans or other forms of inward investment' (Evans, 2006:11). In this type of transfer, the recipient countries are usually denied freedom of policy choice. This is the case because resources are used as incentive or punishment to influence policy transfer. In the context of Africa, donors' approach has been that no policy transfer or public sector reform, no money and other forms of development assistance (Evans, 2006; Peters, 1997; Tambulasi, 2011).

Understandably, conditional policy transfer is common across Africa due to the dependence of African governments on financial aids, technology transfer and development assistance on governments in the global north (Benson, 2018; Evans, 2004; Evans \& Davies, 1999). In this context, the decisions to transfer and implement reforms across LDCs are regarded in the second wave literature on policy transfer as the major initiative of the international policy actors not necessarily the recipient governments and other domestic policy actors in Africa. This is because donors in most cases controlled the agenda of negotiations and decide the particular policy that would be transferred to Africa (Dunlop, 2014; Larmour, 2002). Donors targets might not necessarily be to improve service delivery across Africa but: '...to protect their loans and credit facilities granted to Africa countries' (Omoyefa, 2008). Donors' 
involvement in the transfer in some cases is through conditional funding of security, electoral, agricultural, and educational programs across the continent (Burke \& Sridhar, 2013; McGrath $\&$ Maiye, 2010). Although, the use of conditionality by donor organisations and countries might be responsible for public sector reforms, they are not the only causes of policy transfer across LDCs especially in Africa. This is the case because domestic factors and actors are among the critical drivers for policy transfer and public sector reforms across the continent not only donors' conditionality.

The problem is that the second wave literature prioritises external drivers as the major causes of policy transfer and public sector reforms across Africa with little attention to domestic factors. The literature emphasis that donors compel LDCs to introduce policy change in order to secure grants, loans or other forms of inward investment and the recipient countries are denied freedom of choice in that continent (see Benson, 2018; Evans, 2004 2006; Evans \& Davies, 1999). Consequently, the second wave literature concludes that: '...the political economy of most developing countries throughout the 1980s and 1990s has been characterised by the implementation of SAPs in return for investment from IMF, or the World Bank' (Evans, 2009:245). This claim ignores the role of domestic factors and actors especially in Africa capable of causing policy transfer to occur with or without international pressure for reform. Domestic developments in Africa which include the change of government, citizens' demand for change, natural disaster and campaign strategies are capable of causing policy transfer to occur in that continent.

The second wave literature noted that: '...the study of policy transfer is incomplete without an implementation perspectives' (Evans and Davies 1999:379) but failed to outline the factors that shape the outcomes of implementation of transfer across political systems. It considers international pressures from donor countries and organisations as the major determinants of the effective roll-out of reform across LDCs (see Evans \& Davies, 1999; James \& Lodge, 2003). The problem is that this claim largely neglected the role of local policy actors in reform implementation especially in LDCs. Local policy actors such as politicians, career civil servants, students' unions and the citizens play a key role that determine the effective roll-out of the transferred policies across Africa. Local politicians are responsible for the allocation of resources for the effective roll-out of reforms. Career civil servants are officially required to implement government policies and programs which include the internationally endorsed reform strategies adopted by their government. The role of these local actors in policy transfer processes and in determining the outcome of transfer across LDCs should not be overlooked.

Table 2. Summary of the Second Wave Literature on Policy Transfer Framework

\begin{tabular}{|c|c|c|c|c|}
\hline$s / n$ & Key Issue & $\begin{array}{l}\text { Evans and Davies (1999), } \\
\text { James and Lodge (2003), } \\
\text { Evans (2004) arguments }\end{array}$ & Major critique & \\
\hline 1 & $\begin{array}{l}\text { Causes of } \\
\text { policy }\end{array}$ & $\begin{array}{l}\text { - Domestic and } \\
\text { international }\end{array}$ & 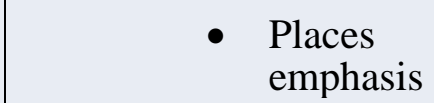 & $\begin{array}{r}\text { more } \\
\text { on }\end{array}$ \\
\hline
\end{tabular}




\begin{tabular}{|c|c|c|c|}
\hline & transfer & factors & $\begin{array}{l}\text { donors' } \\
\text { conditionality as a } \\
\text { major cause of } \\
\text { transfer in LDCs } \\
\text { - Says little on } \\
\text { domestic drivers for } \\
\text { policy transfer } \\
\text { especially in Africa }\end{array}$ \\
\hline 2 & $\begin{array}{l}\text { Factors that shape the } \\
\text { outcomes of } \\
\text { implementation of } \\
\text { transferred policies }\end{array}$ & $\begin{array}{l}\text { - Donors' conditionality } \\
\text { leads to the } \\
\text { implementation of } \\
\text { internationally } \\
\text { formulated reform } \\
\text { strategies across LDCs }\end{array}$ & $\begin{array}{l}\text { - Domestic factors and } \\
\text { actors not only donors } \\
\text { conditions determine the } \\
\text { effective roll-out of } \\
\text { reforms in LDCs } \\
\text { - Does not clearly say how } \\
\text { local non-elite policy } \\
\text { actors shape the outcome } \\
\text { of implementation of } \\
\text { policy transfer across } \\
\text { LDCs }\end{array}$ \\
\hline 3 & Focus of the study & $\begin{array}{l}\text { - Mainly in the global } \\
\text { north } \\
\text { - Emphasis on the role } \\
\text { of elite actors in policy } \\
\text { transfer }\end{array}$ & $\begin{array}{l}\text { - Says little about the } \\
\text { dynamics of transfer in the } \\
\text { global south } \\
\text { - Neglected the role of } \\
\text { non-elite actors in policy } \\
\text { transfer }\end{array}$ \\
\hline
\end{tabular}

Source: Literature review

\section{The Third Wave Literature on Policy Transfer: A New Wave that Addresses the Problems of the First and Second Waves}

The above section presented the second wave literature on policy transfer that critiqued the work of Rose (1991, 1993) on lesson drawing and Dolowitz and Marsh (1996, 2000) on policy transfer. This section presents the third wave framework of understanding the dynamics of policy transfer in LDCs as a new wave that addresses the limitations of the first and the second wave literature. The third wave literature are those that critiqued the first and second wave literature on policy transfer and proposed a new wave which suggests that local context and non-elite policy actors mediate the nature of policy transfer across political systems in LDCs(see Anonymous, 2018; Stone, 2017; Di, 2018; Evans, 2019; Walker, 2019 and Sahin, 2019).

In the last two decades, new frameworks for the study of the dynamics of policy transfer across political systems have emerged. These new perspectives of policy transfer are the Political Nexus Triad (PNT), the third wave policy transfer framework, a multi-level perspective of policy transfer and so on (see Peck \& Theodore, 2001, 2015; Common, 2001, 2004 and Evans \& Davies, 1999, Anonymous, 2018). The central argument of the aforementioned studies is that local context arbitrates the nature of policy transfer and the outcome of their implementations across political systems. But while the aforementioned studies target the role of elite actors in policy transfer, this study is concerned with how the 
conduct of both elite and non-elite policy actors causes policy transfer and the effective implementation of the transferred policy across LDCs. It highlights the domestic contextual factors that mediates the outcome of transfer across political systems especially in Africa. Thus the third wave literature priorities both domestic demand for change and the international pressures as factors responsible for policy transfer across political systems. It argues that local factors and actors not donors' conditionality shape the outcomes of implementation of transferred polices in Africa. The key arguments of the new third wave literature on policy transfer are highlighted below.

i. The occurrence of policy transfer is promoted in situations where there is alignment of domestic aspirations for change and international demand for public sector reforms in Africa (Hadjiisky, Pal, \& Walker, 2017; Liu, Adams, \& Walker, 2018). Domestic factors such as the change of government, natural disasters, and citizens' demand on their government for reforms are capable of causing policy transfer to occur not only international pressures. In Africa, politicians and political parties use policy transfer and public sector reforms as campaign strategies for winning elections (Karyeija, 2012; Alabi, 2012; Lipsky, 2010, Anonymous, 2018). When there is agreement between the global pressure for change and the local desire for reform; career public servants, political parties, academics, and policy experts are engaged in policy transfer from the international arena into their political systems across Africa (Afinotan, 2014; Bates \& Krueger, 1993; Peck \& Theodore, 2001). They are mostly engaged in transfer when they attend formal educational trainings overseas, conferences and official overseas visits to study public sector reforms in other countries.

ii. Change of government especially from military junta to liberal democracy normally provides the much-needed opportunity for both local and international policy actors to introduce new reforms in LDCs (Batley \& Larbi, 2004). This was partly because military governments are hostile to public sector reforms that would improve transparency and accountability in the political system (Okonjo \& Kwaako, 2007; Sokomani, 2009). This is because military government lacks transparency and are not normally accountable to the people. They are in most cases not friendly to the transfer of programs, policy ideas, institutions and the adoption of public sector reforms that would promote open government in their political systems. The change of government from military junta to liberal democracy encourages citizens, students, religious and traditional institutions as well as the career civil servants to demand that the new democratic regime implement reforms to improve efficiency, transparency and accountability in the delivery of public services.

iii. Local policy actors not only international pressures mediate the outcomes of implementation of the transferred policies across Africa (Anonymous, 2018; Common, 2004; Massey, 2009; Peck \& Theodore, 2001). Domestic factors and actors shape the outcomes of reforms implementation across political systems in Africa. This is the case because the effective roll-out of public policies and government programs significantly depend on actions of all critical domestic actors including non-elite policy actors who are in most cases responsible for executing government reforms across Africa. Politicians implement reforms that would make them popular and lead to victory in future elections. Any reform that might lead to job losses which would make the party unpopular in the country would face political 
resistance at the level of implementation. In this regard, the effective implementation of reform are constrained by the open or secret political resistance by entrenched vested political interests across political systems in Africa (Anonymous, 2018; Benson \& Jordan, 2011; Walker, 2019 and Sahin, 2019). Understandably, winning future elections has been a major driver for public sector reform by many political parties across Africa and they might not be totally committed to implementing reforms that might affect their electoral chances. This domestic political level commitment in policy transfer and reform implementation is critical across political systems (see McCourt, 2003; Peck \& Theodore, 2001; Hadjiisky, Pal and Walker, 2017; Liu, Adams, and Walker, 2018). It reflects the priorities and orientations of domestic politics and emphasises the importance of socio-political conditions as the determinants of the effective rollout of public sector reforms in the continent. Political support in the terms of adequate financial allocation for reform programs, providing basic infrastructures and training to the personnel responsible for reform implementation are basic local conditions for the effective implementation of the transferred policies in Africa not only donors conditionality. Thus, it is safe to conclude that the disparities in the outcomes of the implementation of transfers between the global north and the global south deeply depends on the variation of institutional, political, cultural contexts (Hadjiisky, Pal and Walker, 2017; Walker, 2019 and Sahin, 2019).

Domestic civil servants' commitment to policy transfer and the implementation of the borrowed ideas and programs is another basic requirement for the effective rollout of policy transfer across Africa (see Walker, 2019 and Sahin, 2019; McCourt et al. 2001; Peck \& Theodore, 2001). They play the dual role of policy making and policy implementation in their jurisdictions. Their support for policy transfer is crucial because they might frustrate the implementation of the transferred policies they are not in support of. They do this by non-compliance with the political directives on reforms and in so doing sabotage policy implementation (see Anonymous, 2018; McCourt et al. 2001; Lispky, 2010). Similarly, the lack of support of policy transfer and reform by the junior civil servants and the citizens can create a problem. It can present a lack of ownership of reform strategies by the junior civil servants who are mostly responsible for implementing government policies including public sector reforms across Africa (Anonymous, 2018; McCourt et al. 2001). Their support for policy transfer and inclusion in the process of transfer are necessary requirements for the effective implementation of transfer ideas across political systems in Africa.

iv. The availability of basic infrastructures and economic conditions of the citizens are important local factors that mediate the outcome of policy transfer across LDCs (see McCourt, 2001; Tambulasi, 2011; Tettey, 2001). These local factors include electricity supply, poverty and educational level, security of life and property and so on. Uninterrupted electricity supply is required for the effective rollout of e-government reforms because it is the electricity that provides power to computers, e-passport machines and other adopted technologies. The availability of the internet to all citizens is a necessary requirement for the success of e-government reforms across political systems in Africa. This matter because when citizens have no access to the internet, the governments' targets for the online service delivery will be ineffective. Citizens need to have uninterrupted access to electricity, internet, 
and have some level of education for them to patronise e-information and e-service. But the availability of these critical infrastructures cannot be guaranteed in many rural areas across Africa (Anonymous, 2018; Sichuan, 2009; Tambulasi, 2011). These decisive infrastructures are among the key determinants of the outcome of implementation of transferred technologies, policy ideas, reform programs and so on across Africa not only donors' conditionality (Benson, 2018). These local conditions matter a great deal in policy transfer because they determine the level of implementations of the transferred reform strategy across the continent.

\section{Theoretical Contributions}

The extant literature prioritise external pressure from donors as the major causes of policy transfer across LDCs and see donors' conditionality as a determinant of the effective roll out of the transferred policies across Africa. This approach neglected the potential role of domestic factors in causing policy transfer and ignores the relevance of local contextual factors and non-elite actors in shaping the outcome of implementation of transferred policies in Africa. It is in this regard that this paper argues that donors might cause policy transfer but they cannot determine the outcome of the implementation of the transferred policy across political systems in Africa. This paper makes a unique contribution by proposing a third wave approach to policy transfer that first prioritises the role of non-elite domestic policy actors in shaping the outcome of implementation of policy transfer across Africa. The study also highlights the relevance of local factors and domestic actors in causing policy transfer to occur across political systems in LDCs.

\section{The Role of Non-elite Policy Actors in the Implementation of Policy Transfer}

While the mainstream public policy literature recognises the roles played by multiple actors, the focus in transfer literature is on elites policy actors. This section analyses the role of other stakeholders: the non-elites, including junior civil servants and citizens who are also involved in policy transfer in LDCs across Africa. The main focus is on how these non-elites-stakeholders determine the outcomes of the transferred policies and programs across Africa. Junior civil servants and the citizens are among the key local policy actors who also shaped the outcomes of implementation of policy transfer and public sector reform across LDCs. The first and the second wave literatures ignored these critical domestic policy actors in the transfer of public sector reform strategies across political systems. Junior civil servants are in practice officially responsible for implementing policies and programs of government (Lipsky, 2010; Anonymous, 2018).

The citizens are the consumers of public goods and services and their exclusion creates a problem of lack of ownership of the transferred reform strategies by government agencies. It might also creates the fear that the successful roll-out of the transferred public sector reform could lead to massive job loses especially among the junior government employees. In addition, it presents a lack of trust of government institutions and confidence in the services they provide among the citizens who are the final consumers due to lack of involvement in the transfer process. As a result, the support for the effective roll-out of the transferred programs from the junior civil servants and the citizens' would likely be mixed because of 
the assumption of job insecurity among this category of government employees. The extant literature argues that an: '...important condition for policy transfer and implementation is that all relevant actors are included in the process' (Evans 2004:120). But the citizens and the junior civil servants as critical stakeholders were not prioritised in the first and second wave literature of policy transfer across political systems. Consequently, this partly leads to lack of ownership of the transferred policies by these domestic critical stakeholders across political systems which leads to policy implementation failures. This paper argues that the ownership of reforms after transfer by all relevant domestic policy actors which in this case includes the citizens and junior civil servants is a necessary condition for the effective implementation of policy transfer across political systems.

The effective roll-out of policy transfer supported by the elites actors such as politicians, and donors can be undermined by bureaucratic resistance from the junior civil servants when they are not in support of such reforms. It is important to note that the lack of involvement of the junior civil servants in the process of transfer across political systems is not a legitimate reason for bureaucratic resistance because the civil service rule does not require the elite actors to involve the non-elite actors in policy transfer. But the non-elite policy actors need to be involved as stakeholders for them to own the transferred policies and patronise the products and services of policy transfer. This is a necessary conditions for a successful roll-out of policy transfer across political systems across LDCs.

\section{Local Factors and Actors not only International Donors' Pressure Shape the Outcome of Implementation of Policy transfer}

Although the mainstream literature on policy transfer focused more on donors' conditionality's as the main determinant of reform implementation across LDCs (see Dolowitz \& Marsh, 1996, 2000), this section demonstrates that local contextual factors and domestic actors not only international pressure determine the outcome of implementation of policy transfer in Africa. The local policy actors include both elite and non-elite actors such as the senior civil servants, politicians, professional and cultural associations, citizens, student unions and the junior government employees among others. These actors should not only be considered as mere local agents of transfer as did by the mainstream literature on policy transfer but as a critical domestic determinant of the outcomes of the implementation of transfer especially in LDCs. Each of them have an important role to play in the transfer process that ultimately shaped the outcomes of the transfer across political systems. While politicians and senior civil servants are mostly involved in policy making including policy transfer, junior civil servants are responsible for implementing government policies and public sector reforms (Anonymous, 2018).

Professionals, cultural and religious leaders give critical advice to senior government officials and politicians on policy matters. Cultural opinions on policy transfer and public sector reforms especially in Africa are important because culture defines what is acceptable and what is not including policy transfer and public sector reforms (Anonymous, 2018 \& Tambulasi, 2011). But the role of culture and the domestic non-elite policy actors in policy transfer across LDCs has been largely ignored in the mainstream literature on policy transfer. 


\section{Ml Macrothink}

Similarly, the extant literature only mentioned citizens as agents of transfer without emphasis the critical role they play in the effective implementation of policy transfer as the final consumers of transfer services. Further more, the literature ignores the important role of student unions as pressure groups and end-users of public policy in the transfer circle. This paper argues that the support of this category of non-elite policy actors in the process of policy transfer is a necessary condition for the effective implementation of the transferred programs across political systems. There is need therefore for the involvement of all these domestic policy actors before, during and after the transfer for the acceptability and the effective roll-out of the transfer especially in LDCs. When any of these local actors is not involved in the process of transfer, it creates a feeling of exclusion and lack of ownership of the transferred programs, institutions, policy and reform strategy.

In addition, the support for the programs, institutions and reform strategy would remain mixed as can be expected with the transfer of reforms that excluded some key local policy actors. Mixed support for policy transfer can lead to poor patronage of reform, institutions and their services. The role of local factors in policy transfer has been discussed in the extant literature (see Benson, 2018, Tambulasi, 2011). In Africa, the domestic setting plays an important role in any reform programmes and should not be ignored by any government or organisations bringing new reforms to the region to avoid unsuccessful implementation of the transferred programs, institutions and policy.

Table 3. Summary of the first and second wave arguments and the third wave proposals

\begin{tabular}{|c|c|c|c|}
\hline Main Issue & $\begin{array}{l}\text { First Wave Literature Arguments } \\
\text { Dolowitz and Marsh (1996, 2000) } \\
\text { explanations }\end{array}$ & $\begin{array}{l}\text { Second Wave Literature } \\
\text { Arguments } \\
\text { Evans and Davies (1999), } \\
\text { James and Lodge (2003), } \\
\text { Evans (2004) arguments }\end{array}$ & $\begin{array}{l}\text { The Third Wave Proposals } \\
\text { Anonymous } \quad(2018) \text {, } \\
\text { Tambulasi (2011) } \\
\text { Stone,(2017); Evans, (2019); } \\
\text { Di, (2018) \& Walker, (2019) }\end{array}$ \\
\hline $\begin{array}{l}\text { Causes of policy } \\
\text { Transfer }\end{array}$ & $\begin{array}{l}\text { Arguments: } \\
\text { - Coercive pressure. One or more } \\
\text { governments/donors can force } \\
\text { another government to accept a } \\
\text { new policy } \\
\text { - The use of conditional modalities } \\
\text { of transfer by donors can lead to } \\
\text { policy transfer } \\
\text { - Voluntary transfer is caused by } \\
\text { dissatisfaction with the status quo } \\
\text { by policy actors Limitations: } \\
\text { - It Ignores domestic coercive and } \\
\text { conditional factors that can cause } \\
\text { policy transfer to occur with or } \\
\text { without international pressure for } \\
\text { reform }\end{array}$ & 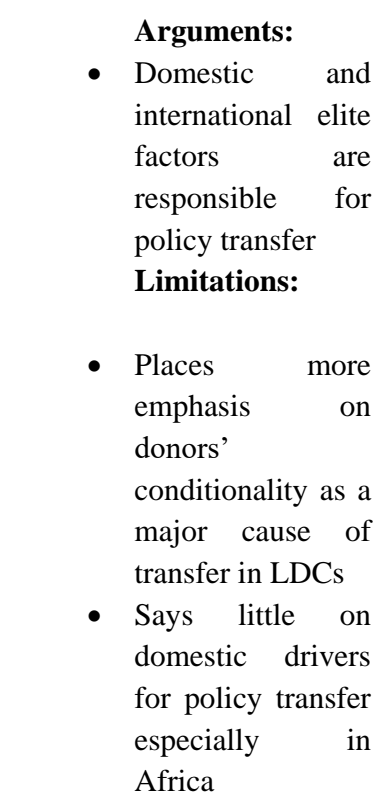 & $\begin{array}{l}\text { - Non-elite domestic } \\
\text { policy actors not } \\
\text { only elite factors are } \\
\text { responsible for } \\
\text { policy transfer } \\
\text { across LDCs }\end{array}$ \\
\hline
\end{tabular}


Factors that shape the outcomes of implementation of transferred policies

Focus of the study
- International pressure can push governments to implement policy transfer for fear of lagging behind and losing the benefits of transfer

- Uninformed, incomplete and inappropriate transfer as reasons for implementation failure. Limitations:

- Domestic factors and actors not only international conditions shape the outcome of implementation transfer in LDCs

- They focus more on reasons for policy transfer failures rather than factors that shape the effective implementation transfer especially LDCs
- Donors'

conditionality leads to the implementation of internationally formulated reform strategies across LDCs

Limitations:

- Domestic factors and actors not only donors' conditions determine the effective roll-out of reforms in LDCs

- Does not clearly say how local policy actors shape the outcome of implementation of policy transfer in LDCs
- Non-elite domestic policy actors partly shaped the outcome

$$
\text { of }
$$
policy implementation

- Local contextual factors with both elite and non-elite domestic policy actors determine the outcome of implementation of policy transfer across LDCs
- Emphasis on the role of elite actors in policy transfer
- Mainly in the global north

- Emphasis on the role of elite actors in policy transfer
- Mainly in the global south

- Emphasis on the role of non-elite actors in policy transfer in LDCs

\section{Source: Literature Review}

\section{Conclusion}

This paper proposed a third wave literature on policy transfer that addresses the existing limitations in the first and second wave literature. It concludes that while the first wave literature failed to give prominence to the importance of local factors in causing policy transfer, the second wave literature say little about how domestic factors can lead to policy transfer to occur especially in LDCs. It is in this regards that the third wave literature examines how both domestic factors and international pressures cause policy transfer across Africa to bridge the gap in the extant literature on transfer in LDCs. The first wave literature on transfer emphasised the use of coercive force by donors to cause policy transfer across LDCs. The second wave literature considers donors pressure as conditions for the effective implementation of the transferred reform strategies across Africa. However, the conclusion drawn from the third wave is that local factors and actors not only donors' conditionality are responsible for policy transfer in LDCs. Similarly, these local factors and actors not donors' 
pressure are the major determinants of the effective implementation of the transferred reform strategies across Africa. This is more so because coercive policy transfer is no longer common given that many political systems are sovereign entities in the $21^{\text {st }}$ Century.

\section{Reference}

Adamolekun, L., \& Ayo, S. B. (1989). The evolution of the Nigerian federal administration system. Publius: The Journal of Federalism, 19(1), 157-176. https://doi.org/10.1093/oxfordjournals.pubjof.a037761

Adebayo, A. (1981). Principles and practice of public administration in Nigeria: John Wiley $\&$ Sons.

Adegoroye, G. (2006). Public service reform for sustainable development: The Nigerian experience. Paper presented at the A keynote Address delivered at the Commonwealth Advance Seminar, Wellington, New Zealand. 20th Feb-3rd March. Bureau of Public Service Reforms.

Adeyemo, A. (2011). E-government implementation in Nigeria: An assessment of Nigerias global e-gov ranking. Journal of Internet and Information Systems, 2(1), 11-19.

Ajayi, G. (2003). NITDA and ICT in Nigeria" being a paper presented at Round Table on Developing Countries Access to Scientific Knowledge. The Abdus Salam ICTP, Trieste, Italy.

Alabi, R. A. (2012). Sectoral Analysis of Impact of Foreign Aid in Nigeria: A Dynamic Specification. Department of Agricultural Economics. Ambrose Alli University, Ekpoma, Nigeria.

Asogwa, B. E. (2013). Electronic government as a paradigm shift for efficient public services: Opportunities and challenges for Nigerian government. Library Hi Tech, 31(1), 141-159. https://doi.org/10.1108/07378831311303985

Ayodele, B., \& Bolaji, K. (2007). Public service and democracy in developing societies: The Nigerian experience. Journal of Social Science, 15(2), 105-110. https://doi.org/10.1080/09718923.2007.11892569

Azeez, N. A., Abidoye, A. P., Adesina, A. O., Agbele, K. K., \& Oyewole, A. (2012). Threats to e-government implementation in the civil service: Nigeria as a case study.

Babalola, Y. T. (2013). Nigeria's information infrastructure policy: implications for e-government. Arabian Journal of Business and Management Review, 2(11), 8-15. https://doi.org/10.12816/0002336

Baecker, D. (1997). The meaning of Culture. Thesis Eleven, 51(1), 37-51. https://doi.org/10.1177/0725513697051000004

Benson, L. (2018). An examination of e-government in the delivery of public services in Nigeria: a policy transfer analysis (Doctoral dissertation, University of Manchester). 
Bernstein, S., \& Cashore, B. (2000). Globalization, four paths of internationalization and domestic policy change: the case of ecoforestry in British Columbia, Canada. Canadian Journal of Political Science/Revue canadienne de science politique, 33(1), 67-99. https://doi.org/10.1017/S0008423900000044

Caiden, G. E. (2011). Administrative reform: Transaction Publishers.

Di, H. (2018). Transfer of Master of Public Information Administration [MPA] program and implementation in China.

Dolowitz, D., \& Marsh, D. (1996). Who learns what from whom: a review of the policy $\begin{array}{llll}\text { transfer literature. } & \text { Political 343-357. }\end{array}$ https://doi.org/10.1111/j.1467-9248.1996.tb00334.x

Dolowitz, D. P. (2000). Policy transfer and British social policy: learning from the USA? : Open Univ Pr.

Dolowitz, D. P., \& Marsh, D. (2000). Learning from abroad: The role of policy transfer in contemporary policy-making. $\quad$ Governance, $\quad$ 13(1), https://doi.org/10.1111/0952-1895.00121

Dunleavy, P., Margetts, H., Bastow, S., \& Tinkler, J. (2006). Digital era governance: IT corporations, the state, and e-government: Oxford University Press. https://doi.org/10.1093/acprof:oso/9780199296194.001.0001

Evans, M. (2019). International policy transfer: between global and sovereign and between global and local. In The Oxford Handbook of Global Policy and Transnational Administration (pp. 1-16). Oxford Univeristy Press. https://doi.org/10.1093/oxfordhb/9780198758648.013.3

Evans, M. (2004). Policy transfer in global perspective: Gower Publishing, Ltd.

Gberevbie, D. E. (2010). Strategies for employee recruitment, retention and performance: Dimension of the Federal civil service of Nigeria. African Journal of Business Management, 4(8), 1447.

Gillies, A. (2007). Obasanjo, the donor community and reform implementation in Nigeria. The Round Table, 96(392), 569-586. https://doi.org/10.1080/00358530701625992

Gualini, E. (2004). Multi-level governance and institutional change: The Europeanization of regional policy in Italy.

Hague, R., Harrop, M., \& McCormick, J. (2016). Political science: A comparative introduction: Palgrave Macmillan. https://doi.org/10.1007/978-1-137-52838-4_15

Heeks, R. (2002). Information systems and developing countries: Failure, success, and local improvisations. The information society, 18(2), 101-112. https://doi.org/10.1080/01972240290075039 


\section{Macrothink}

Journal of Public Administration and Governance ISSN 2161-7104 2021, Vol. 11, No. 1

Ifinedo, P., \& Uwadia, C. (2005). Towards e-government in Nigeria: Shortcomings, successes, swish or sink. Paper presented at the Proceedings of the International Federation of Information Processing (IFIP) WG 9.4 Conference, Abuja, Nigeria.

Ikpeze, N., Soludo, C., \& Elekwa, N. (2004). 13. Nigeria: The Political Economy of the Policy Process, Policy Choice and Implementation. The Politics of Trade and Industrial Policy in Africa: Forced Consensus?, 341.

Karyeija, G. K. (2012). Public sector reforms in Africa: what lessons have we learnt? Paper presented at the Forum for Development Studies. https://doi.org/10.1080/08039410.2011.635378

Lipsky, M. (2010). Street-Level Bureaucracy, 30th Ann. Ed.: Dilemmas of the Individual in Public Service: Russell Sage Foundation.

Maumbe, B. M., Owei, V., \& Alexander, H. (2008). Questioning the pace and pathway of e-government development in Africa: A case study of South Africa's Cape Gateway project. Government information quarterly, 25(4), 757-777. https://doi.org/10.1016/j.giq.2007.08.007

McCourt, W. (2001). The NPM agenda for service delivery: A suitable model for developing countries. The internationalization of public management: Reinventing the Third World state. Edited by: McCourt W, Minogue M. Cheltenham: Edward Elgar, 107-128. https://doi.org/10.4337/9781781952757.00013

The National Economic Empowerment and Development Strategy. (2006).

Nwankwo, G. O. (1988). Education and training for public management in Nigeria: University Publishing Company.

O'neil, P. H. (2015). Essentials of Comparative Politics: Fifth International Student Edition: WW Norton \& Company.

Okonjo-Iweala, N., \& Osafo-Kwaako, P. (2007). Nigeria's economic reforms: Progress and challenges. Brookings Global Economy and Development Working Paper (6). https://doi.org/10.2139/ssrn.1080251

Okosun, J. (1997). Poverty Alleviating Programmes within Structural Adjustment Programmes, (SAP) Framework in Nigeria: An impact Evaluation. Nigerian Journal of Social and Management Sciences, 2(1).

Omitola, B. (2012). Nigerian public service reforms and the fourth republic experience: Challenges and prospects. Journal of Sustainable Development in Africa, 14(8), 76-93.

Omoyefa, P. S. (2008). Public sector reforms in Africa: A philosophical re-thinking. Africa Development, 33(4). https://doi.org/10.4314/ad.v33i4.57332

Pollitt, C., \& Bouckaert, G. (2004). Public management reform: A comparative analysis: Oxford University Press, USA. 


\section{Macrothink}

Journal of Public Administration and Governance ISSN 2161-7104 2021, Vol. 11, No. 1

Rokhman, A. (2011). e-Government adoption in developing countries; the case of Indonesia. Journal of Emerging Trends in Computing and Information Sciences, 2(5), 228-236.

Şahin, S. Z. (2019). The urbanization policy of Turkey: an uneasy symbiosis of unimplemented policy with centralized pragmatic interventions. Turkish Studies, 20(4), 599-618. https://doi.org/10.1080/14683849.2019.1602826

Schuppan, T. (2009). E-Government in developing countries: Experiences from sub-Saharan $\begin{array}{llll}\text { Africa. Government information } & \text { quarterly, 26(1), }\end{array}$ https://doi.org/10.1016/j.giq.2008.01.006

Simwanza, J., Samaratunge, R., \& Trade, E.-M. (2010). Public Sector Reforms in Africa: A Comparison of Zambia and Botswana. International Research Society for Public Management [IRSPM XIII], Berne, Switzerland.

Stone, D. (2004). Transfer agents and global networks in the 'transnationalization' of policy. Journal of European public policy, 11(3), 545-566. https://doi.org/10.1080/13501760410001694291

Stone, D. (2017). Understanding the transfer of policy failure: bricolage, experimentalism $\begin{array}{lllll}\text { and translation. } & \text { Policy } \& \quad \text { Politics, } & \text { 45(1), }\end{array}$ https://doi.org/10.1332/030557316X14748914098041

Tambulasi, R. I. C. (2011). Policy transfer and service delivery transformation in developing countries: the case of Malawi health sector reforms. University of Manchester.

Tettey, W. J. (2001). Information technology and democratic participation in Africa. Journal of Asian and African Studies, 36(1), 133-153. https://doi.org/10.1177/002190960103600107

Therkildsen, O., \& Development, U. N. R. I. f. S. (2001). Efficiency, accountability and implementation: public sector reform in East and Southern Africa: United Nations Research Institute for Social Development.

Walker, C. K. (2019). Policy transfer in a corporatist context: Agents, adjustments and continued innovation. Public Policy and Administration, 34(3), 308-328. https://doi.org/10.1177/0952076718754617

\section{Copyright Disclaimer}

Copyright for this article is retained by the author(s), with first publication rights granted to the journal.

This is an open-access article distributed under the terms and conditions of the Creative Commons Attribution license (http://creativecommons.org/licenses/by/4.0/). 